Portland State University

PDXScholar

\title{
A Functional Application of the Gut-Brain Axis: a Proposed Nutrition Intervention for the Treatment of Depression
}

Tory H. Kusich

Portland State University

Follow this and additional works at: https://pdxscholar.library.pdx.edu/honorstheses

Let us know how access to this document benefits you.

\section{Recommended Citation}

Kusich, Tory H., "A Functional Application of the Gut-Brain Axis: a Proposed Nutrition Intervention for the Treatment of Depression" (2018). University Honors Theses. Paper 580.

https://doi.org/10.15760/honors.589

This Thesis is brought to you for free and open access. It has been accepted for inclusion in University Honors Theses by an authorized administrator of PDXScholar. Please contact us if we can make this document more accessible: pdxscholar@pdx.edu. 
A Functional Application of the Gut-Brain Axis: A Proposed Nutrition Intervention for the Treatment of Depression

by

Tory H. Kusich

An undergraduate honors thesis submitted in partial fulfillment of the requirements for the degree of

Bachelor of Science degree

in

University Honors

and

Applied Health and Fitness

Thesis Adviser

Claire Wheeler MD, Ph.D.

Portland State University 


\section{Table of Contents}

Abstract: 2

$\begin{array}{lr}\text { Introduction: } & \mathbf{3}\end{array}$

- Depression Significance and Diagnostic Criteria

- Depression as an Inflammatory Disease

- Study Aims

The Gut-Brain Axis:

- The Gut-Brain Axis as a Mediator of Depression

- The Gut-Microbiome - An Ecosystem Within Us

- From Probiotics to Psychobiotics

- Probiotics for Depression (Table 1)

- Research Significance and Recommendations

The Role of Nutrition:

- The Importance of Diet and Prebiotics

- Dietary Patterns

The Mediterranean Diet and the Gut Microbiome

- The Mediterranean Diet: What is it?

- Mediterranean Diet Carbohydrates (Prebiotics)

- Mediterranean Diet Proteins

- Mediterranean Diet Fats

Conclusions

- Summary of Research

- Proposed Nutrition Intervention

- Future Perspectives

- Limitations

References 


\begin{abstract}
In the last 10 years, research on the human microbiome has grown exponentially due to the increasing understanding of its effects on human health. The gut-brain axis has become one area of focus, linking gut health and mental disorders. This review of the literature will examine the connection between depression and gut health, primarily mediated by the gut microflora. Due to the complex nature of studying the gut-brain axis and the heterogeneity of depression, recent studies have faced some difficulty in finding significant results based on isolated nutrients, foods, supplements, or probiotics. This proposal seeks to build on prior research to produce an inclusive whole food-based nutrition intervention that potentially will have a more significant impact on depressive disorders. This research will be combining well studied probiotics with a beneficial dietary pattern in the hopes of creating a protocol that yields a more pronounced reduction on depressive symptoms, which could be used in a clinical trial or as an adjuvant treatment.

Keywords: Gut-Brain Axis, Depression, Mental Health, Gut Microbiome, Probiotics, Prebiotics, Psychobiotics, Mediterranean Diet, Dietary Patterns, Nutrition Intervention
\end{abstract}




\section{Introduction}

\section{Depression Significance and Diagnostic Criteria}

Depression is one of the most common mental disorders globally and a leading cause of disability affecting more than 300 million people worldwide (Kessler \& Bromet, 2013; World Health Organization, 2018). Depression greatly reduces quality of life and can have major personal, professional, and social consequences. It also has the capability to bring on suicidal thoughts and potentially lead to death (Popa \& Ladea, 2012). According to the Diagnostic and Statistical Manual of Mental Disorders (5th ed.), the myriad of depressive disorders share common diagnostic criteria including: "the presence of sad, empty, or irritable mood, accompanied by somatic and cognitive changes that significantly affect the individual's capacity to function" (American Psychiatric Association, 2013). The different types of depressive disorders primarily differ because of timing, duration, or presumed etiology (American Psychiatric Association, 2013). It is understood that depression can stem from biological, social, and environmental factors. The present research seeks to address possible biological and environmental origins of depression.

\section{Depression as an Inflammatory Disease}

Current pharmacological treatments for depression involve the use of medications that primarily function to adjust neurotransmitter activity, but these treatments can cause severe side effects and withdrawal symptoms (National Institute of Mental Health, 2018; Wallace \& Milev, 2017). A recent study examining the efficacy on antidepressants found them to be much less clinically significant than previously thought (Moncrieff \& Kirsch, 2005). The common notion that depression stems solely from neurochemical imbalances has more recently been reconsidered and depression is now hypothesized to be an inflammatory disease (Berk et al., 
2013). Common biomarkers of depression include elevations of pro-inflammatory cytokines including interleukin-6 (IL-6), interleukin-8 (IL-8), tumor necrosis factor - alpha (TNF-a), and c-reactive protein (CRP) (Dowlati et al., 2010; Gururajan, Clarke, Dinan, \& Cryan, 2016). It's also common to see evidence of stress-related physiology, such as elevated cortisol levels (Connor \& Leonard, 1998). Brain-related biomarkers of depression include lowered levels of dopamine, serotonin Gamma-Aminobutyric Acid (GABA), and various neurotrophic factors, especially brain-derived neurotrophic factor (BDNF) (Strawbridge, Young, \& Cleare, 2017; Gururajan et al., 2016). All these biomarkers suggest depression to be highly correlated to inflammation, stress, immune dysfunction, and a hyperactive hypothalamus-pituitary-adrenal (HPA) axis (Sandhu et al., 2017).

\section{Study Aims}

Berk et al. (2013) have examined the many possible sources of inflammation that may be influencing depression. Sources of inflammation can stem from biological, social, and environmental factors which helps explain the heterogeneity of depression. Research has shown a strong correlation between depression and gastrointestinal dysfunction, shown in the comorbidity of depression with many gastrointestinal disorders and related inflammatory responses (Mangiola et al., 2016). This has led to an increased interest in studies surrounding nutritional psychiatry, neurogastroenterology, and the gut-brain-axis (Logan \& Katzman, 2005). This paper will be examining the role of dietary patterns and gut microflora as mediators of depression to culminate a nutrition intervention that may potentially prevent or treat depression. 


\section{Gut-Brain Axis}

\section{The Gut-Brain Axis as a Mediator of Depression}

In the last decade, a growing field of research has emerged looking into the bidirectional connection between the central nervous system (CNS) and the gastrointestinal (GI) tract, which is now known as the gut-brain axis. The cross talk between the GI tract and the CNS is mediated through the autonomic and enteric nervous systems, immune system, and endocrine system (Sandhu et al., 2017). The human GI tract is also home to over 100 trillion bacteria which make up the gut microbiome. This microbiome is a very influential part of the gut-brain axis and has a significant impact on human health by maintaining the intestinal barrier, supporting immune function, metabolizing nutrients, producing short chain fatty acids (SCFAs), and producing neurochemicals, such as $90 \%$ of the bodies serotonin (Mangiola et al., 2016; Sandhu et al., 2017). The importance of nutrition and maintaining a healthy gut microbiome has been well established, but the role these play in psychiatric disorders is emerging in research with promising findings. The gut microbiome may modulate cognitive functioning and behavior through possible mechanisms involving the immune system, HPA axis, inflammation, and the production of neurochemicals and neurohormones (Sandhu et al., 2017). Maintenance of a healthy gut microbiome has the potential to modulate levels of anti-inflammatory cytokines, reduce oxidative stress, and increase BDNF, GABA, and serotonin, all of which have negative correlations with depression (Logan \& Katzman, 2005).

\section{The Gut-Microbiome - An Ecosystem Within Us}

The gut microflora is unique to every individual and is influenced by several factors including genetics, lifestyle, birthing method, antibiotic history, and dietary patterns (Sandhu et al., 2017). It is well established which bacteria are beneficial versus harmful, and the balance 
between positive and negative species is essential to host health. An unbalanced microflora is known as dysbiosis and is directly correlated to a plethora of disorders and diseases, one of which being depression. Although everyone's microbiome is distinct, similar populations share certain species, quantities, and diversity (Sandhu et al., 2017). Healthy individuals are primarily populated by the phyla Firmicutes and Bacteroidetes, which contain many beneficial species including the well-known Bifidobacterium and Lactobacillus (Johnson et al., 2012). Individuals with depressive disorders have shown to have an abundance of Enterobacteriaceae (phyla containing mostly pathogenic species), and lower levels of Bifidobacterium and Lactobacillus (gram positive beneficial bacteria) when compared to healthy subjects (Aizawa et al., 2016; Jiang et al., 2015; Sandhu et al., 2017). In a study by Zheng et al. (2016), fecal microflora from patients with major depressive disorder (MDD) were transplanted into germ free mice. This induced depressive-like behaviors and caused metabolic dysfunction when compared to mice who received fecal microflora transplants from healthy subjects (Zheng et al., 2016). There have been numerous other demonstrations that depression may stem from negative alterations in gut microflora.

\section{From Probiotics to Psychobiotics}

Probiotics are defined as "live microorganisms that, when administered in adequate amounts, confer a health benefit on the host" (Hill et al., 2014, p. 506). Probiotics have been prescribed by doctors for many gut-related disorders, but as the understanding of the gut-brain axis has evolved a new era of probiotics has been termed "psychobiotics" for their influence on the CNS, cognition, and behavior (Dinan, Stanton, \& Cryan, 2013). In a systematic review on the effects of probiotics on the CNS, it was found that probiotics can improve CNS functioning possibly through increasing BDNF levels, enhancing serum tryptophan, and decreasing pro- 
inflammatory cytokines (Wang, Lee, Braun, Enck, 2016). In a study on Ulcerative Colitis, probiotics were found to diminish inflammation by decreasing IL-6 and TNF-a concentrations, both of which are inflammatory biomarkers of depression (Hegazy \& El-Bedewy, 2010). Akkasheh et al. (2015), found that probiotic treatment to patients with MDD significantly reduced signs of oxidative stress and CRP levels, other inflammatory biomarkers of depression. A growing body of research is examining the efficacy of specific probiotic strains for the treatment of depression, those with promising results are summarized and presented in Table 1. These studies focus on increasing the quantity and diversity of beneficial gut bacteria, primarily using Bifidobacteria and Lactobacillus supplementation, to bring dysbiotic microflora back to a healthy status.

\section{Table 1. Probiotics for Depression}

This table provides a list of probiotic strains with corresponding evidence in preclinical and clinical studies for the treatment of depressive disorders or associated risk factors. Clinical diagnosis, method of probiotic treatment, and depression scales may differ between studies due to the heterogeneity of depression.

\begin{tabular}{|l|l|l|l|}
\hline Probiotic Strain & \multicolumn{1}{|c|}{ Authors } & \multicolumn{1}{|c|}{ Study Design } & \multicolumn{1}{c|}{ Overview } \\
\hline B. bifidum & $\begin{array}{l}\text { Akkasheh et al. } \\
(2016)\end{array}$ & $\begin{array}{l}\text { Randomized } \\
\text { double-blind } \\
\text { placebo } \\
\text { controlled }\end{array}$ & $\begin{array}{l}\text { Probiotic formula (L. acidophilus, L. casei, } B . \\
\text { bifidum) administered to 20 patients with MDD } \\
\text { over 8 weeks significantly decreased scores on } \\
\text { Beck Depression Inventory }\end{array}$ \\
\hline & $\begin{array}{l}\text { Steenbergen et } \\
\text { al. (2015) }\end{array}$ & $\begin{array}{l}\text { Triple-blind, } \\
\text { placebo } \\
\text { controlled, } \\
\text { randomized, pre } \\
\text { and post } \\
\text { intervention } \\
\text { assessment }\end{array}$ & $\begin{array}{l}\text { 20 healthy participants were administered a } \\
\text { probiotic formulation of B. Bifidum, B. lactis, } L . \\
\text { acidophilus, L. brevis, L, casei, L. salvarius, and } \\
\text { L. lactis for a 4-week period. Leiden Index of } \\
\text { Depression Sensitivity Scale was used to } \\
\text { measure cognitive reactivity to sad mood (a } \\
\text { precursor for depression) and the probiotic } \\
\text { formulation showed significant reductions on } \\
\text { scale. }\end{array}$ \\
\hline B. infantis & $\begin{array}{l}\text { Desbonnet et al. } \\
\text { (2010) }\end{array}$ & $\begin{array}{l}\text { Preclinical } \\
\text { animal study }\end{array}$ & $\begin{array}{l}\text { B. Infantis proved to be nearly as effective as } \\
\text { citalopram (a common antidepressant) in }\end{array}$ \\
\hline
\end{tabular}




\begin{tabular}{|c|c|c|c|}
\hline & & & $\begin{array}{l}\text { normalizing forced swim test behaviors in a rat } \\
\text { maternal separation model, which is a reliable } \\
\text { marker of antidepressant activity. }\end{array}$ \\
\hline B. lactis & $\begin{array}{l}\text { Steenbergen et } \\
\text { al. (2015) }\end{array}$ & $\begin{array}{l}\text { Triple-blind, } \\
\text { placebo } \\
\text { controlled, } \\
\text { randomized, pre } \\
\text { and post } \\
\text { intervention } \\
\text { assessment }\end{array}$ & $\begin{array}{l}20 \text { healthy participants were administered a } \\
\text { probiotic formulation of B. Bifidum, B. lactis, } L \text {. } \\
\text { acidophilus, } L \text {. brevis, L, casei, L. salvarius, and } \\
\text { L. lactis for a 4-week period. Leiden Index of } \\
\text { Depression Sensitivity Scale was used to } \\
\text { measure cognitive reactivity to sad mood (a } \\
\text { precursor for depression) and the probiotic } \\
\text { formulation showed significant reductions on } \\
\text { scale. }\end{array}$ \\
\hline \multirow[t]{2}{*}{ B. longum } & $\begin{array}{l}\text { Messaoudi et } \\
\text { al. (2011) }\end{array}$ & $\begin{array}{l}\text { Randomized } \\
\text { double- blind } \\
\text { placebo } \\
\text { controlled }\end{array}$ & $\begin{array}{l}\text { The probiotic formula of } L \text {. helveticus and } B \text {. } \\
\text { longum reduced anxiety and in preclinical rats } \\
\text { and had beneficial psychological effects } \\
\text { (including depression reduction) in } 26 \text { human } \\
\text { volunteers. }\end{array}$ \\
\hline & $\begin{array}{l}\text { Pinto-Sanchez } \\
\text { et al. (2017) }\end{array}$ & $\begin{array}{l}\text { Randomized } \\
\text { double-blind } \\
\text { placebo } \\
\text { controlled pilot } \\
\text { study }\end{array}$ & $\begin{array}{l}\text { Pilot study found that } B \text {. longum reduces } \\
\text { depression and increases quality of life in } 22 \\
\text { patients with IBS compared to controls. }\end{array}$ \\
\hline \multirow[t]{2}{*}{ L. acidophilus } & $\begin{array}{l}\text { Akkasheh et al. } \\
\text { (2016) }\end{array}$ & $\begin{array}{l}\text { Randomized } \\
\text { double-blind } \\
\text { placebo } \\
\text { controlled }\end{array}$ & $\begin{array}{l}\text { Probiotic formula (L. acidophilus, L. casei, B. } \\
\text { bifidum) administered to } 20 \text { patients with MDD } \\
\text { over } 8 \text { weeks significantly decreased scores on } \\
\text { Beck Depression Inventory }\end{array}$ \\
\hline & $\begin{array}{l}\text { Steenbergen et } \\
\text { al. (2015) }\end{array}$ & $\begin{array}{l}\text { Triple-blind, } \\
\text { placebo } \\
\text { controlled, } \\
\text { randomized, pre } \\
\text { and post } \\
\text { intervention } \\
\text { assessment }\end{array}$ & $\begin{array}{l}20 \text { healthy participants were administered a } \\
\text { probiotic formulation of } B \text {. Bifidum, B. lactis, } L \text {. } \\
\text { acidophilus, } L \text {. brevis, } L \text {, casei, } L \text {. salvarius, and } \\
\text { L. lactis for a } 4 \text {-week period. Leiden Index of } \\
\text { Depression Sensitivity Scale was used to } \\
\text { measure cognitive reactivity to sad mood (a } \\
\text { precursor for depression) and the probiotic } \\
\text { formulation showed significant reductions on } \\
\text { scale. }\end{array}$ \\
\hline L. brevis & $\begin{array}{l}\text { Steenbergen et } \\
\text { al. (2015) }\end{array}$ & $\begin{array}{l}\text { Triple-blind, } \\
\text { placebo } \\
\text { controlled, } \\
\text { randomized, pre } \\
\text { and post } \\
\text { intervention }\end{array}$ & $\begin{array}{l}20 \text { healthy participants were administered a } \\
\text { probiotic formulation of } B \text {. Bifidum, B. lactis, } L \text {. } \\
\text { acidophilus, } L \text {. brevis, } L \text {, casei, } L \text {. salvarius, and } \\
\text { L. lactis for a } 4 \text {-week period. Leiden Index of } \\
\text { Depression Sensitivity Scale was used to } \\
\text { measure cognitive reactivity to sad mood (a }\end{array}$ \\
\hline
\end{tabular}




\begin{tabular}{|c|c|c|c|}
\hline & & assessment & $\begin{array}{l}\text { precursor for depression) and the probiotic } \\
\text { formulation showed significant reductions on } \\
\text { scale. }\end{array}$ \\
\hline \multirow[t]{2}{*}{ L. casei } & $\begin{array}{l}\text { Akkasheh et al. } \\
\text { (2016) }\end{array}$ & $\begin{array}{l}\text { Randomized } \\
\text { double-blind } \\
\text { placebo } \\
\text { controlled }\end{array}$ & $\begin{array}{l}\text { Probiotic formula (L. acidophilus, L. casei, B. } \\
\text { bifidum) administered to } 20 \text { patients with MDD } \\
\text { over } 8 \text { weeks significantly decreased scores on } \\
\text { Beck Depression Inventory }\end{array}$ \\
\hline & $\begin{array}{l}\text { Steenbergen et } \\
\text { al. }(2015)\end{array}$ & $\begin{array}{l}\text { Triple-blind, } \\
\text { placebo } \\
\text { controlled, } \\
\text { randomized, pre } \\
\text { and post } \\
\text { intervention } \\
\text { assessment }\end{array}$ & $\begin{array}{l}20 \text { healthy participants were administered a } \\
\text { probiotic formulation of } B \text {. Bifidum, B. lactis, } L \text {. } \\
\text { acidophilus, } L \text {. brevis, } L \text {, casei, } L \text {. salvarius, and } \\
\text { L. lactis for a 4-week period. Leiden Index of } \\
\text { Depression Sensitivity Scale was used to } \\
\text { measure cognitive reactivity to sad mood (a } \\
\text { precursor for depression) and the probiotic } \\
\text { formulation showed significant reductions on } \\
\text { scale. }\end{array}$ \\
\hline L. helveticus & $\begin{array}{l}\text { Messaoudi et } \\
\text { al. (2011) }\end{array}$ & $\begin{array}{l}\text { Randomized } \\
\text { double- blind } \\
\text { placebo } \\
\text { controlled }\end{array}$ & $\begin{array}{l}\text { The probiotic formula of } L \text {. helveticus and } B \text {. } \\
\text { longum reduced anxiety and in preclinical rats } \\
\text { and had beneficial psychological effects } \\
\text { (including depression reduction) in } 26 \text { human } \\
\text { volunteers. }\end{array}$ \\
\hline L. plantarum & $\begin{array}{l}\text { Liu et al. } \\
\text { (2016) }\end{array}$ & $\begin{array}{l}\text { Preclinical } \\
\text { animal study }\end{array}$ & $\begin{array}{l}\text { L. plantarum effectively decreased serum IL-6 } \\
\text { levels and improved depressive behaviors in } \\
\text { mice with early life stress }\end{array}$ \\
\hline L. reuteri & $\begin{array}{l}\text { Ma, Forsythe, } \\
\text { \& Bienenstock } \\
\text { (2004) }\end{array}$ & Preclinical study & $\begin{array}{l}\text { L. Reuteri directly inhibited IL-8 and TNF-alpha, } \\
\text { promoting an anti-inflammatory effect on human } \\
\text { epithelial cells. }\end{array}$ \\
\hline L. rhamnosus & $\begin{array}{l}\text { Slykerman et } \\
\text { al. (2017) }\end{array}$ & $\begin{array}{l}\text { Randomized } \\
\text { double-blind } \\
\text { placebo } \\
\text { controlled }\end{array}$ & $\begin{array}{l}\text { Study showed a significant reduction of } \\
\text { depressive and anxiety postpartum symptoms in } \\
212 \text { women compared to placebo group. }\end{array}$ \\
\hline L. salivarius & $\begin{array}{l}\text { Steenbergen et } \\
\text { al. (2015) }\end{array}$ & $\begin{array}{l}\text { Triple-blind, } \\
\text { placebo } \\
\text { controlled, } \\
\text { randomized, pre } \\
\text { and post } \\
\text { intervention } \\
\text { assessment }\end{array}$ & $\begin{array}{l}20 \text { healthy participants were administered a } \\
\text { probiotic formulation of } B \text {. Bifidum, B. lactis, } L \text {. } \\
\text { acidophilus, } L \text {. brevis, } L \text {, casei, L. salvarius, and } \\
\text { L. lactis for a 4-week period. Leiden Index of } \\
\text { Depression Sensitivity Scale was used to } \\
\text { measure cognitive reactivity to sad mood (a } \\
\text { precursor for depression) and the probiotic } \\
\text { formulation showed significant reductions on } \\
\text { scale. }\end{array}$ \\
\hline
\end{tabular}




\section{Research Significance and Recommendations}

Based on the results of these articles, it's reasonable to conjecture that a combination of these beneficial probiotic species may be a promising option for the prevention and treatment of depression. An important thing to mention is that few of these studies have large sample sizes, control for diet and prebiotic consumption, use modes of transmission beside capsulized probiotics, or analyze the stool to confirm the probiotics were able to colonize in the lower GI tract. The efficacy of probiotics relies on their ability to survive through the stomach and adhere permanently to the epithelium of the large intestine. Their ability to do so depends on how the cultures were administered, the presence of prebiotics, and the quantity and quality of the probiotic culture (Johnson et al., 2012). Although these studies have found clinically relevant and promising results, it is possible that these findings could be improved if more measures are taken to ensure the colonization of probiotic species in the GI tract.

\section{The Role of Nutrition}

\section{The Importance of Diet and Prebiotics}

The most effective way to rapidly improve the gut microbiome and promote the colonization and growth of beneficial species is through diet (Singh et al., 2017). Although the use of probiotic supplements has demonstrated potential effectiveness in promoting the integrity of the microbiome and improving depressive symptoms, research suggests that the influence of a healthy diet and consumption of probiotic foods and drinks may be more influential (Walker et al, 2011). The probiotic research presented in Table 1 primarily establishes what specific species show the most promise in influencing mood and depressive symptoms. These "psychobiotic" species include B. bifidum, B. infantis, B. lactis, B. longum, L. acidophilus, L. brevis, L. casei, L. helveticus, L. plantarum, L. reuteri, L. rhamnosus, and L. salivarius. These species can be found 
in a variety of fermented foods and drinks including fermented dairy products, sauerkraut, kimchi, kombucha, etc. Another main way diet supports microbiome health is from the presence of prebiotics, specific nondigestible foodstuffs, that feed beneficial bacteria which then outcompete harmful species (Singh et al, 2017). Prebiotics include fructooligosaccharides, galactooligosaccharides, lactulose, cereal fibers, resistant starches, lactosucrose, soybean, and oligosaccharides (Johnson et al., 2012). To see more significant clinical results for treating depression the consumption of probiotics, prebiotics, and quality of diet must be established to improve the gut microbiome and feed these psychobiotic species.

\section{Dietary Patterns}

A fundamental approach to achieving optimal function of the gut-brain axis is through specific nutritional interventions focused on dietary patterns. While some research has focused on the use of specific vitamins, minerals, and other supplements to promote gut and brain health, results are mixed (Wallace \& Milev, 2017). This has led many to propose that, rather than focusing on isolated nutrients, examining diet patterns as a whole may be more impactful when studying mental health, especially depression (Del Chierico, Vernocchi, Dallapiccola, \& Putignani, 2014). There is a growing body of research that supports the Mediterranean diet as an effective prevention or treatment plan for depression as they are inversely related (Psaltopoulou et al., 2013; Sanchez-Villegas et al., 2007; Sandhu et al., 2017). Correspondingly, there is a strong correlation between the Western diet (high in refined carbohydrates, animal protein and fat) and depression, along with the comorbidity of many other metabolic disorders (Jacka et al, 2010; Psaltopoulou et al., 2013). Studies continue to evaluate the possible antidepressant properties of the Mediterranean dietary pattern, one of which may be the positive impact it has on the gut microbiome (Sanchez-Villegas et al., 2007). Research has compared the influence of 
dietary patterns on gut microflora and found that Western diets limit microflora density and show a reduction in amounts of Bifidobacteria and Lactobacillus and an increase in Enterobacteria (Singh et al., 2017). On the other hand, the Mediterranean diet increases microflora diversity and promotes the growth of Bifidobacteria and Lactobacillus (see figure 1.) (Singh et al., 2017).

Figure 1. Western diet vs. Mediterranean diet effects on microflora (Singh et al., 2017).
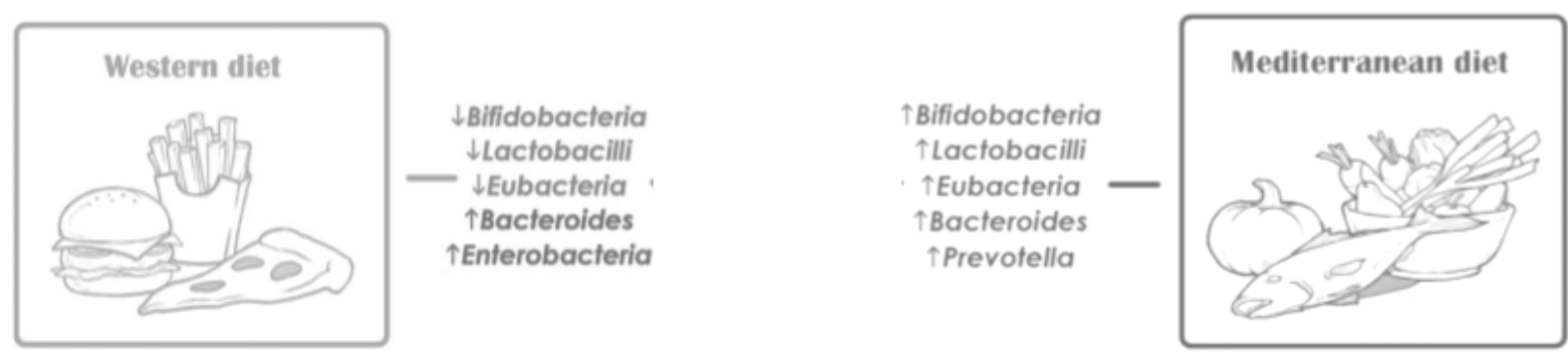

\section{The Mediterranean Diet and the Gut Microbiome}

\section{The Mediterranean Diet: What is it?}

The Mediterranean diet has come to be known as one of the healthiest and most beneficial ways of eating. The Mediterranean diet is an eating pattern characterized by daily intake of unrefined grains, vegetables, fruit, olive oil, and dairy, with a moderate intake of fish, poultry, eggs, sweets, and legumes, and rarely red meat. (see figure 2). 
Figure 2. The Mediterranean Diet food pyramid (Trichopoulou, 2004).

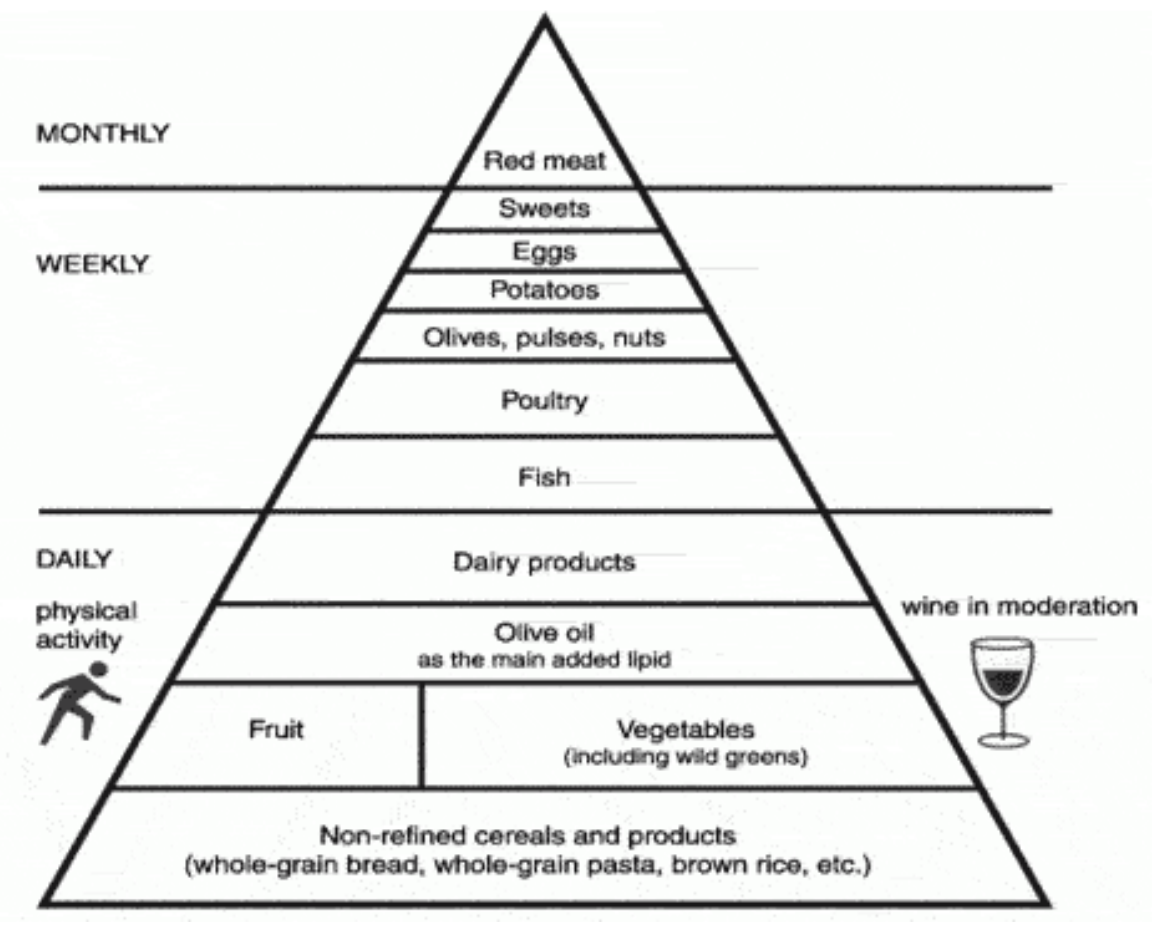

\section{Mediterranean Diet Carbohydrates (Prebiotics)}

In a study done by Filippis et al. (2016), the microbiomes of 153 volunteers were analyzed in relation to their adherence to a Mediterranean diet. The results of the study found that dietary patterns closest to that of the Mediterranean diet were associated with healthier microbiome profiles compared to those consuming a Western diet (Filippis et al., 2016). A large portion of the Mediterranean diet is composed of fruits, vegetables, and foods high in fiber, which provide the variety of prebiotics that promote beneficial gut bacteria. Prebiotics, such as fructooligosaccharides, oligosaccharides, cereal fibers, and resistant starches found in the Mediterranean diet, are often indigestible carbohydrates that can only be broken down by beneficial species such as Bifidobacterium and Lactobacillus. The consumption of these prebiotics allows beneficial gut microbes to produce SCFA, such as butyrate, that directly support digestive function and produce anti-inflammatory effects (Singh et al., 2017). Prebiotic consumption is associated with reductions of pro-inflammatory cytokine IL-6, increases in the 
anti-inflammatory cytokine IL-10, and other positive metabolic markers while also increasing microflora density and diversity (Martinez et al., 2013; Singh et al., 2017).

\section{Mediterranean Diet Proteins}

Aside from its high content of beneficial carbohydrates, the Mediterranean dietary pattern also emphasizes a reduced consumption of meat and promotes the ingestion of healthy fats. Meat intake and fat quality have also shown to influence the composition of the gut microbiome and may add to the success of the Mediterranean diet in reducing depression. Plant protein rich diets increase microflora diversity and can increase beneficial microbes, but diets with high consumption of animal-based protein produce an opposite effect. Diets high in animal-based protein increase counts of Bacteroides, Alistipes, and Bilophila, which increase protein fermentation that lead to toxic metabolites. These metabolites are associated with the development of cancer, irritable bowel disease, and cardiovascular disease (Singh et al. 2017; Sandhu et al., 2017). De Filippo et al. (2010), found that an animal protein rich diet produces fewer SCFA's, which protect the gut membrane and reduce inflammation. Diets high in animal protein and low in prebiotic foods promote the colonization of harmful species, which degrades the health of the gut microflora.

\section{Mediterranean Diet Fats}

Other nutrient components of the Mediterranean diet may also serve as protective agents against depression. The emphasis on healthy mono- and polyunsaturated fat (PUFA) consumption in the Mediterranean diet increases omega-3 levels which may play a major role in inflammatory responses (Simopoulos, 2002). The ratio of omega-6 to omega-3 PUFA consumption is understood to be of importance when it comes to human health. A high ratio of omega-6/omega-3 has been highly correlated to inflammatory diseases, especially in Western 
cultures where the average PUFA ratio is 16-1 when it is recommended to be $2-1$ or 1-1

(Simopoulos, 2002). The Mediterranean diet supports a high consumption of fish and olive oil (both high in omega-3) which has shown to decrease pro-inflammatory markers such as IL-6, CRP, and TNF- $a$ (Bountziouka et al., 2009). Studies have shown that a lack of dietary omega-3 is correlated with depression, and populations with a higher PUFA ratio have higher prevalence of major depressive disorders (Bountziouka et al., 2009).

\section{Conclusions}

\section{Summary of Research}

As the understanding of the gut-brain axis evolves, research continues to find connections between depression, gut microflora, and the Mediterranean diet. Studies continue to search for isolated solutions from probiotics and nutritional aspects, but it is apparent the success from recent research stems from a cumulative effect that diet has on the microflora, and that the microflora has on the brain. As depression is now seen as an inflammatory disease, it is crucial to pinpoint the root of this inflammation and find functional ways to reduce it. As the GI tract is the body's largest immune organ, the idea that gut inflammation can be the underlying cause of some depressive disorders is not unlikely. The culmination of this research has uncovered the mechanisms by which diet can improve gut microflora, and in turn may decrease depressive symptoms. Figure 3 presents a simplified version of the mechanistic actions of this nutrition intervention. Essentially, what we eat influences the composition of our gut microbiota and thus what metabolites are produced. When eating a healthy diet rich in probiotics and prebiotics we feed the beneficial microbes in our gut and they return the favor by producing anti-inflammatory metabolites, energy, and beneficial neurochemicals. These metabolites then reduce systemic inflammation by regulating the immune system and calming the HPA axis, which helps bring the 
body back into homeostasis and reduces depressive symptoms. The beneficial neurochemicals produced by the microflora are able to pass the blood-brain barrier and regulate levels of BDNF, GABA, dopamine, and serotonin in the brain, also thus reducing depressive symptoms.

Figure 3. Influence of proposed nutrition intervention on gut microbiome and cognitive functioning.

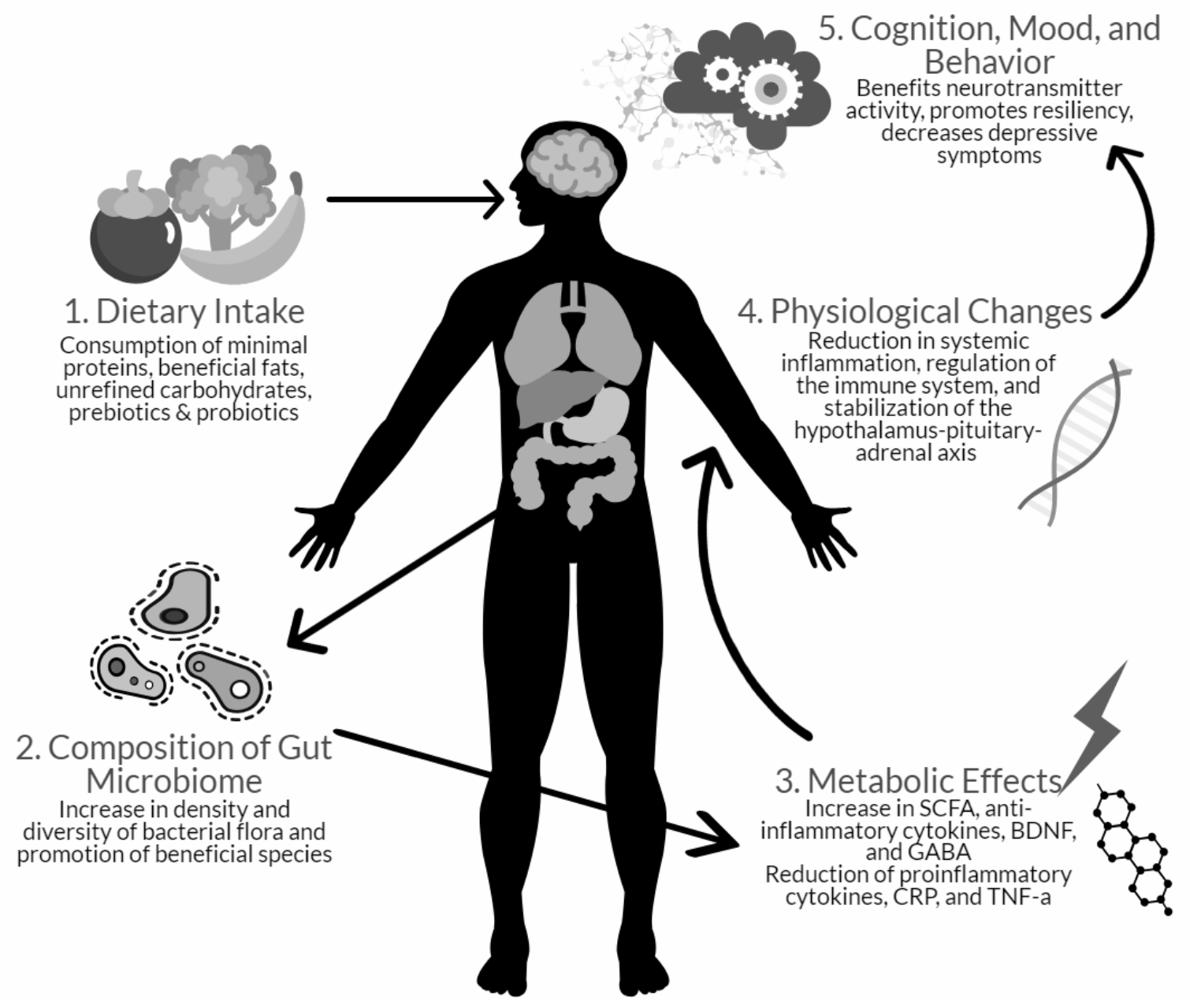

\section{Proposed Nutrition Intervention}

Through this research, a nutrition intervention based on a Mediterranean dietary model with an emphasis on the consumption of probiotic and prebiotic foods may successfully prevent/ treat depressive disorders. The outline of this intervention is presented in Figure 4. 
Figure 4. Nutrition Intervention proposal for the prevention/ treatment of depression.

\section{Nutrition Intervention for Depression}

Foods/Drinks to consume

\section{Daily:}

Unrefined grains
Prebiotic grains to
include:

- Whole grain wheat

- Whole grain cereals

- Oats

- Rice (cooked and cooled)

\section{Any Vegetables}

Prebiotic Vegetables to include in diet are:

- Artichoke

- Asparagus

- Endive

- Jerusalem artichoke

- Garlic

- Onion

- Parsnip

- Leek

- Radishes

- Carrots

- Tomatoes

- Jicama

- Yams

- Spinach

- Potatoes (cooked and cooled)

\section{Any Fruits}

Prebiotic fruits include:

- Green bananas

- Apples

- Blueberries

Any Legumes and Seeds Prebiotics include:

- Chia seeds

- Flax seeds

- legumes in general
Healthy Fats

- Olive oil

- Avocado oil

- Coconut oil

\section{Probiotic foods}

- Kimchi

- Sauerkraut

- Kefir

- Tempeh

- Kombucha

- Pickled foods

- Miso

- Olives

- Probiotic enriched dairy (or dairy alternatives)

Probiotic Species (in foods or supplements)

- B.bifidum

- B. infantis

- B. lactis

- B. longum

- L. acidophilus

- L. brevis

- L. casei

- L. helveticus

- L. plantarum

- L. reuteri

- L. rhamnosus

- L. salivarius

\section{Water}

2 liters is recommended
Moderately:

Fish and seafood

At least twice a week

Dairy Products

Preferably containing probiotics and less sugar

Poultry/Eggs

Antibiotic-free

\section{Rarely:}

Red meat

Antibiotic free and

preferably grass

fed/sustainable

\section{Sweets}

This includes refined grains and anything high in sugar 
This nutrition intervention is not all inclusive, but a recommendation based on the present research. This intervention is a non-harmful, holistic, accessible, and potentially effective way to prevent or manage depressive symptoms. For depressed populations who have a history of antibiotic use, poor dietary habits, or other inflammatory or GI problems (such as eczema or IBS) this nutrition intervention could serve as an extremely beneficial solution. This intervention is not meant to replace current depression treatments and individuals should always consult their physician before making any large scale dietary changes. This recommendation is meant to be a supplemental, holistic way to potentially address depression and more research is needed to support its efficacy in clinical trials.

\section{Future Perspectives}

In the future, research on this topic must approach it from a more functional direction by implementing larger scale nutrition interventions and probiotic treatments to modulate depression. Present research focused on isolated nutrients and single probiotic strains continues to show promise but lacks large sample sizes and high significance. No single nutrient or single probiotic strain is going to solve the depression epidemic. Dietary habits need to be controlled, effective methods to promote probiotic colonization need to be used, and stool samples must be analyzed to produce more conclusive results. Diet, microflora, and mood are clearly interrelated, and more research is necessary to reveal the mystery of this connection. As projects such as the Human Microbiome Project (National Institute of Health) make advancements in uncovering the complex world of our microbiomes, more studies need to solidify the best practices for ensuring colonization of beneficial microbes in the GI tract and how nutrition affects the ecosystem in our gut. Research on the gut microbiome and the influence of nutrition expands beyond depression to a variety of other psychiatric disorders, as well as numerous metabolic disorders. As this field of 
research grows, it is very clear the ecosystems within our bodies may play a much larger role in our mental health than previously understood.

\section{Limitations}

One of the main limitations of this research is the heterogeneity of depression and how this causes many discrepancies among current research. There are a multitude of diagnoses for depressive disorders and a similar plethora of scales to measure them. The present research only addresses depression from an inflammatory perspective that focuses on inflammation stemming from the gut. This does not account for possible other roots of inflammation but may serve as a way to promote anti-inflammatory responses systemically. This nutrition intervention may not be applicable among all people due to the personalized nature of the gut microbiome. Some research has supported a personalized nutrition intervention based off individual microbiomes and genetics. The present approach supports a general dietary plan that can be modified by individuals and is based off the healthiest dietary model currently acknowledged by science. 


\section{References}

Aizawa, E., Tsuji, H., Asahara, T., Takahashi, T., Teraishi, T., Yoshida, S., ... Kunugi, H. (2016). Possible association of Bifidobacterium and Lactobacillus in the gut microbiota of patients with major depressive disorder. Journal of Affective Disorders, 202, 254-257. https://doi.org/10.1016/j.jad.2016.05.038

Akkasheh, G., Kashani-Poor, Z., Tajabadi-Ebrahimi, M., Jafari, P., Akbari, H., Taghizadeh, M., ... Esmaillzadeh, A. (2016). Clinical and metabolic response to probiotic administration in patients with major depressive disorder: A randomized, double-blind, placebo-controlled trial. Nutrition, 32(3), 315-320. https://doi.org/10.1016/j.nut.2015.09.003

American Psychiatric Association. (2013). Depressive disorders. Diagnostic and Statistical Manual of Mental Disorders (5th ed.). https://doi.org/10.1176/appi.books.9780890425596.dsm04

Berk, M., Williams, L. J., Jacka, F. N., O’Neil, A., Pasco, J. A., Moylan, S., ... Maes, M. (2013). So depression is an inflammatory disease, but where does the inflammation come from? BMC Medicine, 11, 200. https://doi.org/10.1186/1741-7015-11-200

Bountziouka, V., Polychronopoulos, E., Zeimbekis, A., Papavenetiou, E., Ladoukaki, E., Papairakleous, N., ... Panagiotakos, D. (2009). Long-Term Fish Intake Is Associated With Less Severe Depressive Symptoms Among Elderly Men and Women: The MEDIS (MEDiterranean ISlands Elderly) Epidemiological Study. Journal of Aging and Health, 21(6), 864-880. https://doi.org/10.1177/0898264309340693 
Connor, T. J., \& Leonard, B. E. (1998). Depression, stress and immunological activation: The role of cytokines in depressive disorders. Life Sciences, 62(7), 583-606. https://doi.org/10.1016/S0024-3205(97)00990-9

De Filippo, C., Cavalieri, D., Di Paola, M., Ramazzotti, M., Poullet, J. B., Massart, S., ... Lionetti, P. (2010). Impact of diet in shaping gut microbiota revealed by a comparative study in children from Europe and rural Africa. Proceedings of the National Academy of Sciences of the United States of America, 107(33), 14691-14696. https://doi.org/10.1073/pnas.1005963107

Del Chierico, F., Vernocchi, P., Dallapiccola, B., \& Putignani, L. (2014). Mediterranean Diet and Health: Food Effects on Gut Microbiota and Disease Control. International Journal of Molecular Sciences, 15(7), 11678-11699. https://doi.org/10.3390/ijms150711678

Desbonnet, L., Garrett, L., Clarke, G., Kiely, B., Cryan, J. F., \& Dinan, T. G. (2010). Effects of the probiotic Bifidobacterium infantis in the maternal separation model of depression. Neuroscience, 170(4), 1179-1188. https://doi.org/10.1016/j.neuroscience.2010.08.005

Dinan, T. G., Stanton, C., \& Cryan, J. F. (2013). Psychobiotics: A Novel Class of Psychotropic. Biological Psychiatry, 74(10), 720-726. https://doi.org/10.1016/j.biopsych.2013.05.001

Dowlati, Y., Herrmann, N., Swardfager, W., Liu, H., Sham, L., Reim, E. K., \& Lanctôt, K. L. (2010). A meta-analysis of cytokines in major depression. Biological Psychiatry, 67(5), 446-457. https://doi.org/10.1016/j.biopsych.2009.09.033

Filippis, F. D., Pellegrini, N., Vannini, L., Jeffery, I. B., Storia, A. L., Laghi, L., ... Ercolini, D. (2016). High-level adherence to a Mediterranean diet beneficially impacts the gut microbiota and associated metabolome. Gut, 65(11), 1812-1821. https://doi.org/10.1136/gutjnl-2015-309957 
Gururajan, A., Clarke, G., Dinan, T. G., \& Cryan, J. F. (2016). Molecular biomarkers of depression. Neuroscience \& Biobehavioral Reviews, 64, 101-133. https://doi.org/10.1016/j.neubiorev.2016.02.011

Hegazy, S. K., \& El-Bedewy, M. M. (2010). Effect of probiotics on pro-inflammatory cytokines and NF- $\mathrm{KB}$ activation in ulcerative colitis. World Journal of Gastroenterology: WJG, 16(33), 4145-4151. https://doi.org/10.3748/wjg.v16.i33.4145

Hill, C., Guarner, F., Reid, G., Gibson, G. R., Merenstein, D. J., Pot, B., ... Sanders, M. E. (2014). Expert consensus document: The International Scientific Association for Probiotics and Prebiotics consensus statement on the scope and appropriate use of the term probiotic. Nature Reviews Gastroenterology \& Hepatology, 11(8), 506-514. https://doi.org/10.1038/nrgastro.2014.66

Jacka, F. N., Pasco, J. A., Mykletun, A., Williams, L. J., Hodge, A. M., O’Reilly, S. L., ... Berk, M. (2010). Association of Western and Traditional Diets With Depression and Anxiety in Women. American Journal of Psychiatry, 167(3), 305-311. https://doi.org/10.1176/appi.ajp.2009.09060881

Jiang, H., Ling, Z., Zhang, Y., Mao, H., Ma, Z., Yin, Y., ... Ruan, B. (2015). Altered fecal microbiota composition in patients with major depressive disorder. Brain, Behavior, and Immunity, 48, 186-194. https://doi.org/10.1016/j.bbi.2015.03.016

Johnson, L. R., Ghishan, F. K., Kaunitz, J. D., Merchant, J. L., Said, H. M., \& Wood, J. (2012). Gastrointestinal Microbial Ecology with Perspectives on Health and Disease, in M.G. Gillilland, V. B. Young, \& G.B. Huffnagle, Physiology of the Gastrointestinal Tract (pp. 1119-1134). San Diego, CA: Elsevier Science \& Technology 
Kessler, R. C., \& Bromet, E. J. (2013). The epidemiology of depression across cultures. Annual Review of Public Health, 34, 119-138. https://doi.org/10.1146/annurev-publhealth031912-114409

Liu, Y.-W., Liu, W.-H., Wu, C.-C., Juan, Y.-C., Wu, Y.-C., Tsai, H.-P., ... Tsai, Y.-C. (2016). Psychotropic effects of Lactobacillus plantarum PS128 in early life-stressed and naïve adult mice. Brain Research, 1631, 1-12. https://doi.org/10.1016/j.brainres.2015.11.018

Logan, A. C., \& Katzman, M. (2005). Major depressive disorder: probiotics may be an adjuvant therapy. Medical Hypotheses, 64(3), 533-538. https://doi.org/10.1016/j.mehy.2004.08.019

Ma, D., Forsythe, P., \& Bienenstock, J. (2004). Live Lactobacillus reuteri Is Essential for the Inhibitory Effect on Tumor Necrosis Factor Alpha-Induced Interleukin-8 Expression. Infection and Immunity, 72(9), 5308-5314. https://doi.org/10.1128/IAI.72.9.5308-5314.2004

Mangiola, F., Ianiro, G., Franceschi, F., Fagiuoli, S., Gasbarrini, G., Gasbarrini, A. (2016). Gut microbiota in autism and mood disorders. World Journal of Gastroenterology, 22(1), 361-368. http://dx.doi.org/10.3748/wjg.v22.i1.361

Martínez, I., Lattimer, J. M., Hubach, K. L., Case, J. A., Yang, J., Weber, C. G., ... Walter, J. (2013). Gut microbiome composition is linked to whole grain-induced immunological improvements. The ISME Journal, 7(2), 269-280. https://doi.org/10.1038/ismej.2012.104 
Messaoudi, M., Lalonde, R., Violle, N., Javelot, H., Desor, D., Nejdi, A., ... Cazaubiel, J.-M. (2011). Assessment of psychotropic-like properties of a probiotic formulation Lactobacillus helveticus R0052 and Bifidobacterium longum R0175 in rats and human subjects. British Journal of Nutrition, 105(5), 755-764. https://doi.org/10.1017/S0007114510004319

Moncrieff, J., \& Kirsch, I. (2005). Efficacy of antidepressants in adults. BMJ, 331(7509), 155-157. https://doi.org/10.1136/bmj.331.7509.155

National Institute of Mental Health. (2018). Depression. Retrieved from https://www.nimh.nih.gov/health/topics/depression/index.shtml

Pinto-Sanchez, M.I., Hall, G.B., Ghajar, K., Nardelli, A., Bolino, C., Lau, J.T., ... Berick, P. (2017). Probiotic Bifidobacterium longum NCC3001 Reduces Depression Scores and Alters Brain Activity: A Pilot Study in Patients With Irritable Bowel Syndrome. Gastroenterology. 153(2). 448-459. https://doi.org/10.1053/j.gastro.2017.05.003

Popa, T., \& Ladea, M. (2012). Nutrition and depression at the forefront of progress. Journal of Medicine and Life, 5(4), 414-419.

Psaltopoulou, T., Sergentanis, T. N., Panagiotakos, D. B., Sergentanis, I. N., Kosti, R., \& Scarmeas, N. (2013). Mediterranean diet, stroke, cognitive impairment, and depression: A meta-analysis. Annals of Neurology, 74(4), 580-591. https://doi.org/10.1002/ana.23944

Sanchez-Villegas, A., Henríquez, P., Figueiras, A., Ortuño, F., Lahortiga, F., \& Martínez-González, M. A. (2007). Long chain omega-3 fatty acids intake, fish consumption and mental disorders in the SUN cohort study. European Journal of Nutrition, 46(6), 337-346. https://doi.org/10.1007/s00394-007-0671-X 
Sandhu, K. V., Sherwin, E., Schellekens, H., Stanton, C., Dinan, T. G., \& Cryan, J. F. (2017).

Feeding the microbiota-gut-brain axis: diet, microbiome, and neuropsychiatry.

Translational Research, 179, 223-244. https://doi.org/10.1016/j.trsl.2016.10.002

Simopoulos, A. P. (2002). The importance of the ratio of omega-6/omega-3 essential fatty acids.

Biomedicine \& Pharmacotherapy, 56(8), 365-379.

https://doi.org/10.1016/S0753-3322(02)00253-6

Singh, R. K., Chang, H.-W., Yan, D., Lee, K. M., Ucmak, D., Wong, K., ... Liao, W. (2017). Influence of diet on the gut microbiome and implications for human health. Journal of Translational Medicine, 15. https://doi.org/10.1186/s12967-017-1175-y

Slykerman, R. F., Hood, F., Wickens, K., Thompson, J. M. D., Barthow, C., Murphy, R., ... Probiotic in Pregnancy Study Group. (2017). Effect of Lactobacillus rhamnosus HN001 in Pregnancy on Postpartum Symptoms of Depression and Anxiety: A Randomised Double-blind Placebo-controlled Trial. EBioMedicine, 24, 159-165. https://doi.org/10.1016/j.ebiom.2017.09.013

Strawbridge, R., Young, A. H., \& Cleare, A. J. (2017). Biomarkers for depression: recent insights, current challenges and future prospects. Neuropsychiatric Disease and Treatment, 13, 1245-1262. https://doi.org/10.2147/NDT.S114542

Steenbergen, L., Sellaro, R., Hermet, S.V., Bosch, J. A., Colzato, L.S. (2015). A randomized controlled trial to test the effect of multispecies probiotics on cognitive reactivity to sad mood. Brain, Behavior, and Immunity, 48, 258-264.

http://dx.doi.org/10.1016/j.bbi.2015.04.003 
Trichopoulou, A. (2004). Traditional Mediterranean diet and longevity in the elderly: a review. Public Health Nutrition, 7(7), 943-947.

Wallace, C. J. K., \& Milev, R. (2017). The effects of probiotics on depressive symptoms in humans: a systematic review. Annals of General Psychiatry, 16, 14. http://doi.org/10.1186/s12991-017-0138-2

Walker, A. W., Ince, J., Duncan, S. H., Webster, L. M., Holtrop, G., Ze, X., ... Flint, H. J. (2011). Dominant and diet-responsive groups of bacteria within the human colonic microbiota. The ISME Journal, 5(2), 220-230. https://doi.org/10.1038/ismej.2010.118

Wang, H. Lee, I., Braun, C., Enck, P. (2016). Effect of probiotics on central nervous system functions in animals and humans: A systematic review. Journal of Neurogastroenterology and Motility, 22(4), 589-605. http://ds.doi.org/10.5056/jnm16018

World Health Organization. (2018). Depression. Retrieved from http://www.who.int/en/news-room/fact-sheets/detail/depression

Zheng, P., Zeng, B., Zhou, C., Liu, M., Fang, Z., Xu, X., ... Xie, P. (2016). Gut microbiome remodeling induces depressive-like behaviors through a pathway mediated by the host's metabolism. Molecular Psychiatry, 21(6), 786-796. https://doi.org/10.1038/mp.2016 